Tersedia online di: http://ejournal-balitbang.kkp.go.id/index.php/bawal
e-mail:bawal.puslitbangkan@ gmail.com
BAWAL WIDYA RISET PERIKANAN TANGKAP
Volume 10 Nomor 1 April 2018
p-ISSN: 1907-8226
e-ISSN: 2502-6410
BAWAL
Nomor Akreditasi: 620/AU2/P2MI-LIPI/03/2015

\title{
BEBERAPAASPEK BIOLOGI UDANG WINDU (Penaeus monodon (Fabricus, 1789) DI PERAIRAN TARAKAN, KALIMANTAN UTARA
}

\section{SOME BIOLOGICALASPECTS OF TIGER SHRIMP(Penaeus monodon, Fabricus, 1789) IN TARAKAN WATERS, NORTH KALIMANTAN}

\author{
Umi Chodrijah*1 dan Ria Faizah ${ }^{2}$ \\ ${ }^{1}$ Balai Riset Perikanan Laut, Kompl. Raiser Jl. Raya Bogor KM. 47, Cibinong, Jawa Barat, Indonesia \\ ${ }^{2}$ Pusat Riset Perikanan, Jl. Pasir Putih II, Ancol Timur, Jakarta Utara-14430, Indonesia \\ Teregistrasi I tanggal: 29 Mei 2017; Diterima setelah perbaikan tanggal: 12 Februari 2018; \\ Disetujui terbit tanggal: 13 Februari 2018
}

\begin{abstract}
ABSTRAK
Udang windu merupakan salah satu komoditas ekonomis di Indonesia dan sudah dimanfaatkan serta dikembangkan cukup lama di perairan Tarakan sehingga perlu upaya pengelolaan dengan salah satu dasar kajian biologinya. Penelitian ini membahas beberapa aspek biologi udang windu, meliputi hubungan panjang-berat, nisbah kelamin, kematangan kelamin, serta ukuran rata-rata tertangkap dan matang kelamin. Penelitian dilakukan selama bulan Januari-November 2016. Hasil penelitian menunjukkan, dari 2208 ekor contoh udang windu yang dianalisa, ukuran yang tertangkap berkisar antara 21,9-63 mmCL serta hubungan panjang-bobot menyatakan pola pertumbuhan isometrik. Musim pemijahan diduga terjadi sepanjang tahun dengan puncak pemijahan pada bulan Maret-April dan September. Nisbah kelamin udang berada dalam kondisi tidak seimbang dan didominasi oleh betina. Rata-rata ukuran pertama kali tertangkap (Lc) adalah pada panjang karapas 40,69 mmCL serta ratarata ukuran matang gonad ( $\mathrm{Lm})$ udang betina adalah 33,58 mmCL.
\end{abstract}

Kata Kunci: Aspek biologi; udang windu; Tarakan; WPP 716

\section{ABSTRACT}

Tiger shrimp (Penaeus monodon, Fabricus, 1789) was one of economic commodity of shrimp in Indonesia and had been historically exploited that required a proper management measure based on biology study. The research aims to examine biological aspects of tiger shrimp such as length-weigth relationship, sex ratio, maturity stage and length of first capture $(L c)$ and length of first maturity $(L m)$. The research was carried out from January to November 2016 using survey method and the monthly enumeration programme. The result of 2.208 individual tiger shrimp analysed showed that size of tiger shrimp range between 21.9-63 $\mathrm{mmCL}$ with the growth follows a isometric pattern. Spawning season occurs throughout the year with peak season in MarchApril and September. Sex ratio was in an unbalanced condition dominated by females. The length of first capture (Lc) was $40.69 \mathrm{mmCL}$ and length of first maturity $(\mathrm{Lm})$ was $33.58 \mathrm{mmCL}$.

Keywords: Biological; tiger shrimp; Tarakan; FMA 716

\section{PENDAHULUAN}

Perairan Tarakan merupakan bagian dari WPP716 (Laut Sulawesi) yang memiliki sumberdaya perikanan cukup beragam dan bernilai ekonomis penting. Potensi sumberdaya ikan yang paling menonjol di perairan Tarakan adalah jenis-jenis ikan demersal seperti ikan nomei, bambangan, kakap, kerapu, gulamah senangin dan krustase (udang dan kepiting). Sumberdaya udang yang telah dimanfaatkan dan dikembangkan di daerah ini antara lain udang penaeid seperti udang windu atau tiger, jerbung, dogol dan krosok. Udang windu (Penaeus monodon) merupakan salah satu jenis komoditas udang ekonomis di Indonesia diantara komoditas udang lainnya. Produksi udang windu Indonesia yang berasal dari penangkapan sekitar 34.784 ton. Selama 4 tahun terakhir (2011-2014) produksi udang windu mengalami kenaikan sebesar $31,67 \%$ (DJPT, 2015). 
Penangkapan udang di perairan Tarakan berlangsung sepanjang tahun dengan menggunakan alat tangkap pukat hela dengan ukuran mata jaring 1,5 inch dan kantong sebesar 1 inch (BPPL, 2012). Penangkapan yang dilakukan terus menerus tanpa kontrol pemanfaatan yang baik akan menyebabkan menurunnya stok dan potensi sumber daya udang.

Dalam Kepmen No 47 Tahun 2016 tercantum potensi udang penaeid di WPP 716 sebesar 8.465 ton dengan tingkat pemanfaatan sebesar 0,75 yang artinya sudah mengalami fully exploited. Kondisi demikian memerlukan pengelolaan agar tidak mengancam kelestarian dari udang windu di alam. Oleh karena itu perlu data dan informasi aspek biologi reproduksi udang windu sebagai salah satu dasar pertimbangan dalam penentuan pengelolaan udang windu di perairan Laut Sulawesi khususnya Tarakan.

Penelitian tentang udang penaeid telah banyak dilakukan di beberapa perairan di Indonesia, antara lain di perairan Arafura (Naamin, 1984), perairan Cilacap (Suman, 1992; Suman \& Broer, 2005; Saputra \& Subiyanto, 2007, Saputra et al., 2013), perairan Kotabaru, Kalimantan Selatan (Suman \& Umar, 2010); perairan Tarakan (Kembaren \& Suman, 2013, Kembaren \& Nurdin, 2013), di perairan Takalar, Sulawesi Selatan (Jamal, 2015), perairan Sampit, Kalimantan Tengah (Nurdin \& Kembaren, 2015), di perairan Aceh (Hedianto et al., 2016). Namun demikian, kajian tentang aspek biologi udang windu masih jarang ditemukan. Tujuan penelitian ini adalah untuk mengetahui beberapa aspek biologi udang windu, meliputi hubungan panjang-berat, nisbah kelamin, kematangan kelamin, serta ukuran rata-rata tertangkap dan matang kelamin. Hasil penelitian ini diharapkan dapat dijadikan sebagai salah satu bahan pertimbangan untuk pengelolaan sumber daya udang di perairan Laut Sulawesi khususnya di perairan Tarakan.

\section{BAHANDANMETODE}

Penelitian dilakukan di perairan Tarakan, Kalimantan Utara pada bulan Januari sampai November 2016. Pengambilan sampel udang windu (Penaeus monodon) sebanyak 2.208 ekor dilakukan di tempat pendaratan udang di Selumit Pantai, Tarakan, Kalimantan Utara pada bulan Januari sampai dengan November 2016 (Gambar 1). Sampel udang merupakan hasil tangkapan pukat hela serta pengumpulan dan pengukuran udang dibantu oleh enumerator di Tarakan, Kalimantan Utara.

Pengamatan sampel udang meliputi pengukuran panjang karapas, berat udang windu, jenis kelamin dan tingkat kematangan gonad. Tingkat kematangan gonad udang ditentukan secara morfologi sesuai dengan kriteria tingkat indeks kematangan gonad udang yang dikemukakan oleh Naamin (1984) yaitu : (1) dara (underveloped), (2) berkembang (developed), (3) hampir matang (early mature), (4) matang (ripe) dan (5) salin (spent). Pada tingkat (1) dan (2) ovarinya adalah bening (translucent), kemudian warna berubah dari pucat menjadi kuning pada tingkat (3) menjadi hijau gelap selama tingkat (4) dan hijau keabu-abuan selama tingkat (5). Tingkat kematangan gonad 1 dan 2 dikelompokkan dalam golongan belum matang dan tingkat kematangan gonad 3 dan 4 sebagai golongan matang gonad.

Analisis data yang dilakukan meliputi struktur ukuran, hubungan panjang berat, nisbah kelamin, Tingkat Kematangan Gonad, rata-rata panjang karapas udang pertama kali matang gonad (Lm) dan rata-rata panjang karapas udang pertama kali tertangkap (Lc).

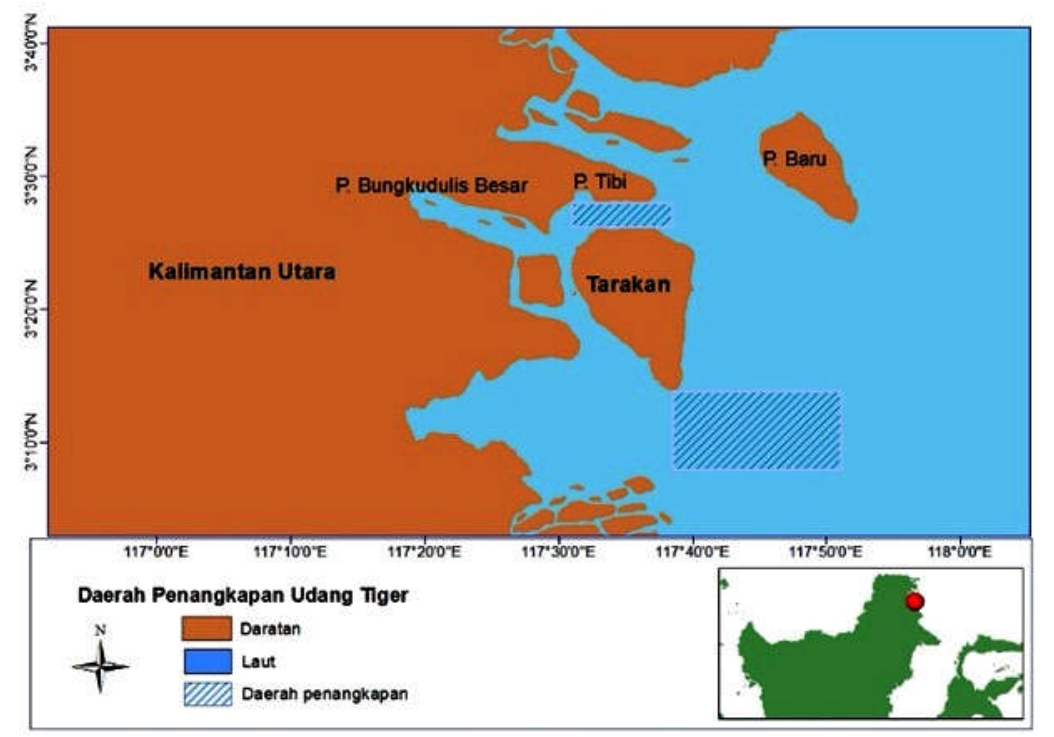

Gambar 1. Lokasi penelitian dan daerah penangkapan udang di Tarakan, Kalimantan Utara.

Figure 1. Map showing research site and shrimping ground in Tarakan, North Kalimantan. 
Hubungan panjang-berat dianalisa mengikuti persamaan eksponensial sebagai berikut (Lagler, 1972; Jennings et al., 2001):

$\mathrm{W}=\mathrm{aL}^{\mathrm{b}}$

dimana;

$\mathrm{W} \quad=$ berat individu udang $(\mathrm{g})$

$\mathrm{L} \quad=$ panjang karapas udang $(\mathrm{mm})$

a dan $b=$ konstanta hasil regresi

Hubungan panjang berat yang telah diperoleh akan diuji dengan uji t (t-test), yaitu menguji nilai $b$ dengan hipotesa:

$\mathrm{H}_{0}: \mathrm{b}=3$ (isometrik)

$\mathrm{H}_{1}: \mathrm{b} \neq 3$ (alometrik)

Jika t-hitung lebih kecil dari t-tabel $\left(\mathrm{t}_{\mathrm{hit}}<\mathrm{t}_{\text {tab }}\right)$ maka terima $\mathrm{H}_{0}$ tolak $\mathrm{H}_{1}$.

Jika t-hitung lebih besar dari t-tabel $\left(\mathrm{t}_{\mathrm{hit}}>\mathrm{t}_{\mathrm{tab}}\right)$ maka terima $\mathrm{H}_{1}$ tolak $\mathrm{H}_{0}$.

Pengujian nisbah kelamin dilakukan dengan uji Chi Kuadrat (Steel \& Torrie, 1989):

$X^{2}=\sum_{i-1}^{k} \frac{(O i-e i)^{2}}{e i}$

dimana;

$\mathrm{Oi}=$ jumlah frekuensi udang jantan dan betina

ei $=$ jumlah udang jantan dan betina harapan pada sel ke-i

$\mathrm{k}=$ kelompok stasiun pengamatan untuk udang jantan dan betina yang ditemukan.

Nilai Lm dianalisis dengan metode Spearman-Karber dalam Udupa (1986) yaitu sebagai berikut:
$\mathrm{m}=\mathrm{Xk}+\mathrm{X} / 2-(\mathrm{X} \mathrm{x}$ Ó pi $)$

dimana;

$\mathrm{m}=$ logaritma ukuran pertama kali matang gonad

$\mathrm{Xk}=$ logaritma nilai tengah kelas terakhir dimana terjadi matang gonad $100 \%$

$\mathrm{X}=$ selisih logaritma nilai tengah

pi $=$ proporsi udang matang gonad pada kelas ke-i

$\mathrm{CL}=\operatorname{Antilog}\left(\mathrm{m} \pm 1,96 \sqrt{\mathrm{X}^{2}\left(\frac{\sum \mathrm{pi} \times \mathrm{qi}}{\mathrm{ni}-1}\right)}\right)$

dimana;

$\mathrm{C}=$ Confident limit (batas atas dan bawah)

$\mathrm{m}=$ panjang karapas udang pertama kali matang gonad

ni $\quad=$ jumlah udang pada kelas panjang ke-i

qi $=1-$ pi.

\section{HASIL DAN BAHASAN}

Hasil

\section{Struktur Ukuran}

Pada Gambar 2 diperlihatkan kisaran panjang karapas udang windu (P. monodon) antara 21,9 mmCL sampai 63 $\mathrm{mmCL}$, rata-rata $40,732 \mathrm{mmCL}(\mathrm{n}=2208)$.

\section{Hubungan Panjang-Berat}

Grafik hubungan antara panjang dan berat udang disajikan pada Gambar 3. Setelah dilakukan uji t dengan tingkat kepercayaan 95\% (á = 0,05), didapatkan pola pertumbuhan udang jantan bersifat isometrik, dimana pertambahan panjang dan berat udang seimbang.

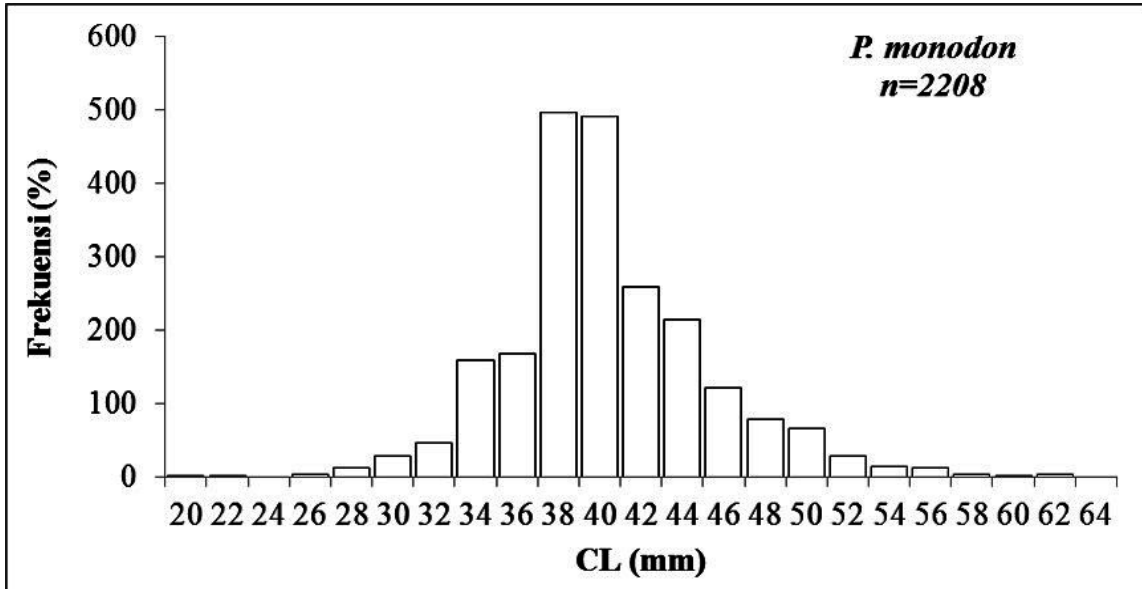

Gambar 2. Distribusi Frekuensi Panjang karapas Udang windu (P. monodon) dari perairan Tarakan.

Figure 2. Length distribution of tiger shrimp (P. monodon) from Tarakan waters. 


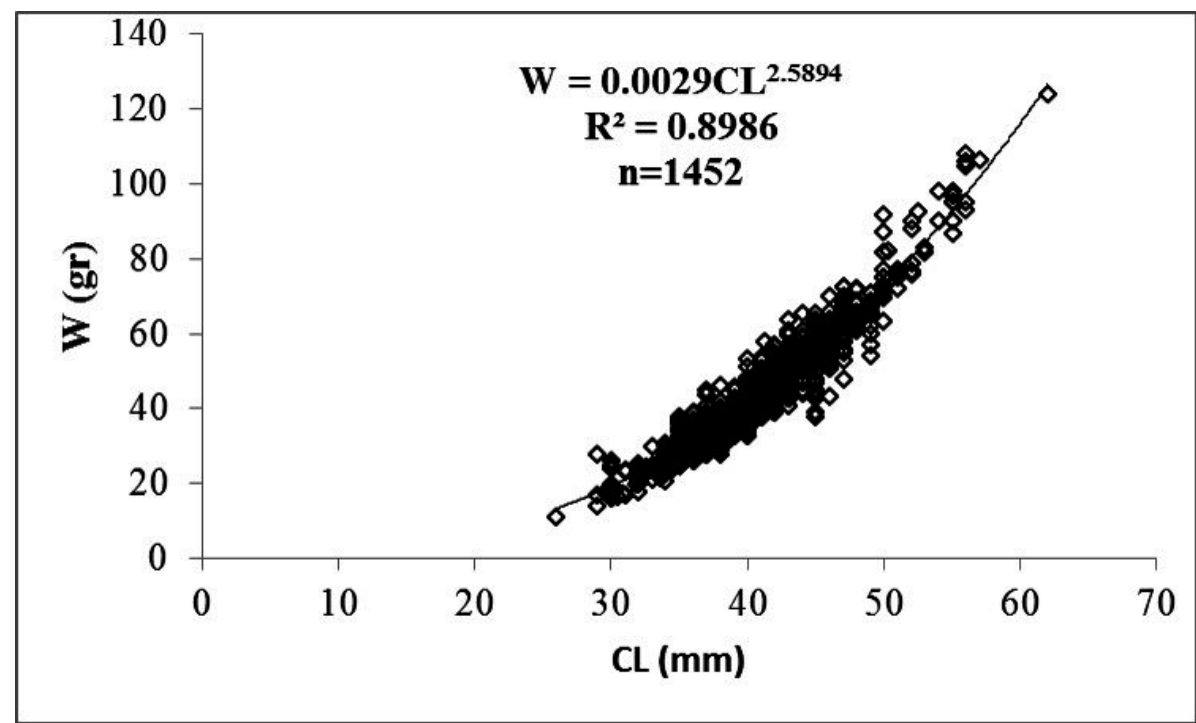

Gambar 3. Hubungan panjang berat udang windu (P. monodon) di perairan Tarakan.

Figure 3. Length weight relationship of tiger shrimp (P. monodon) from Tarakan waters.

\section{Nisbah Kelamin}

Dari perbandingan jenis kelamin udang windu $(P$. monodon) diperoleh rasio jantan : betina yang berbeda pada setiap bulannya. Secara keseluruhan, perbandingan kelamin udang windu (P. monodon) jantan dan betina adalah $1: 1,437$. Variasi perbandingan jenis kelamin udang windu (P. monodon) pada bulan Januari - November 2016 disajikan pada Gambar 4.

\section{Kematangan Kelamin}

Hasil pengamatan terhadap sampel udang windu $(P$. monodon) selama tahun 2016 berbeda pada setiap bulannya. Presentase udang windu (P. monodon) betina matang gonad (mature $=$ TKG III dan IV) yang tinggi ditemukan pada bulan Maret, April dan September disajikan pada Gambar 5.

\section{Rata-rata Ukuran Panjang Pertama Kali Matang Gonad (Lm) dan Rata-Rata Ukuran Pertama Kali Tertangkap (Lc)}

Rata-rata ukuran pertama kali matang gonad udang windu (P. monodon) di perairan Tarakan tahun 2016 diduga 33,58 mmCL, sedangkan rata-rata ukuran panjang pertama kali tertangkap (Lc) sebesar 40,69 mmCL (Gambar 6).

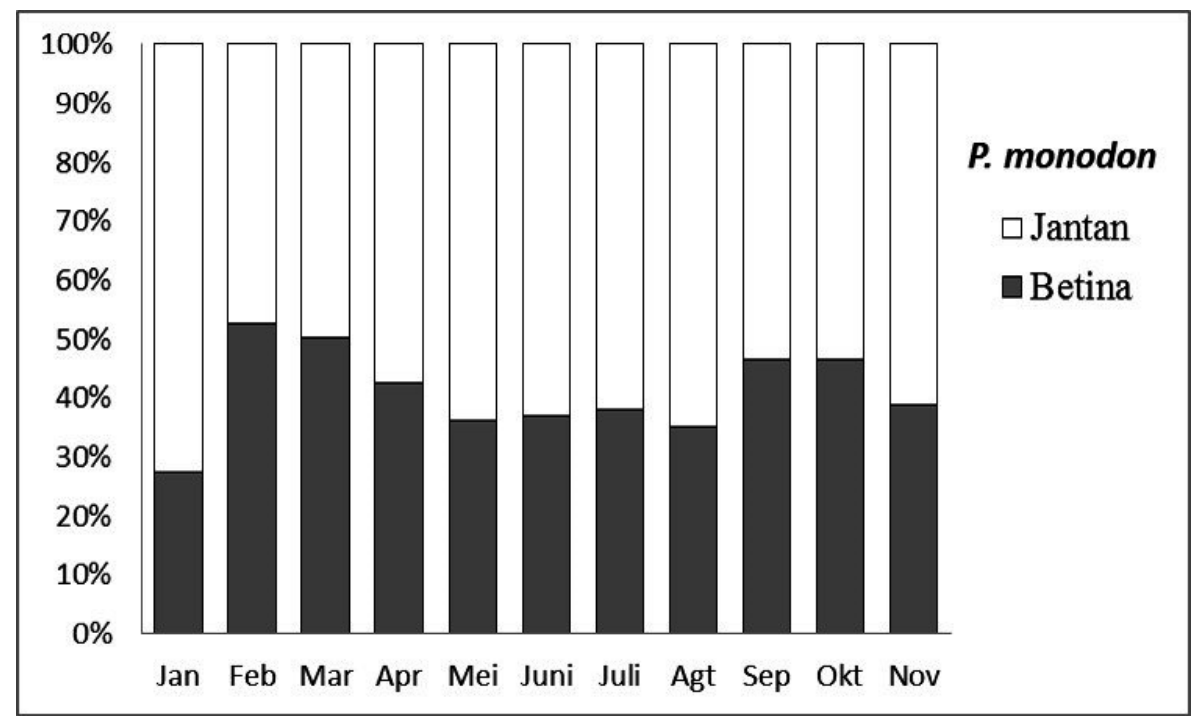

Gambar 4. Variasi perbandingan jenis kelamin udang windu (P. monodon) di perairan Tarakan. Figure 4. Sex ratio of Tiger Shrimp (P. monodon) from Tarakan Waters. 


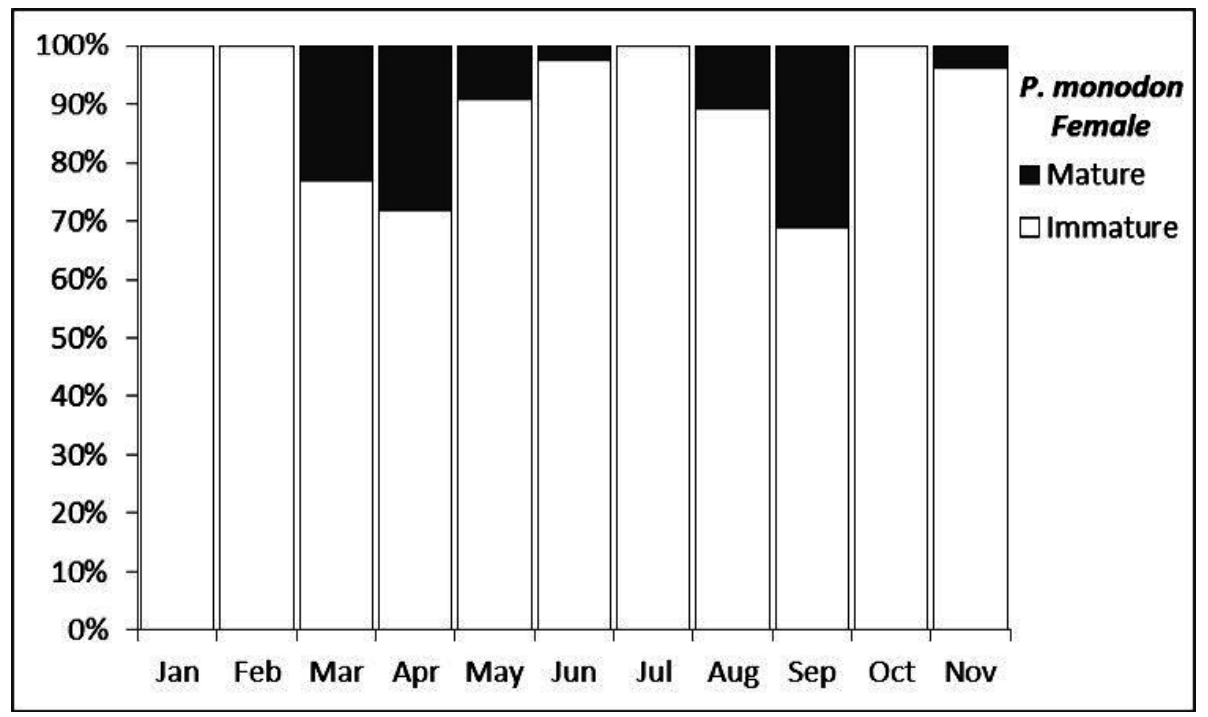

Gambar 5. Perkembangan tingkat kematangan gonad udang windu (P. monodon) di perairan Tarakan.

Figure 5. Gonadal maturity stage of tiger shrimp (P.monodon) in Tarakan waters.

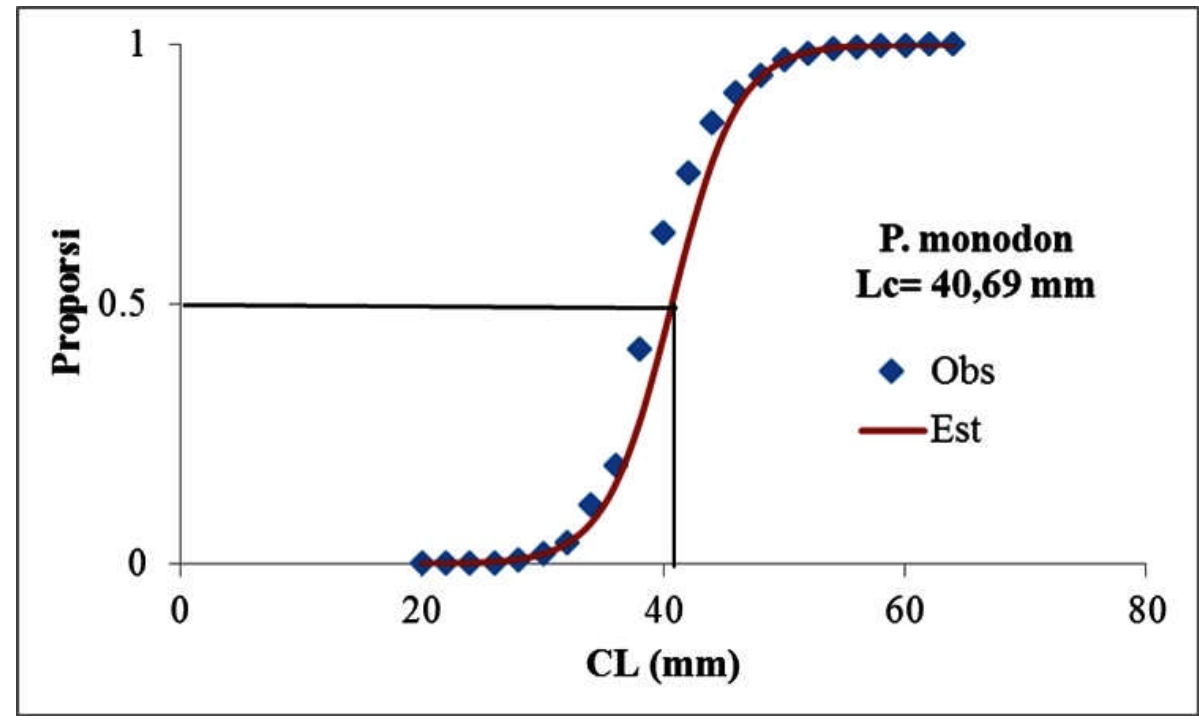

Gambar 6. Rata-rata ukuran pertama kali tertangkap udang windu (P. monodon) di perairan Tarakan.

Figure 6. Length of first capture of tiger shrimp (P.monodon) in Tarakan water.

\section{Bahasan}

Ukuran udang windu yang tertangkap pada penelitian ini berkisar antara 21,9 - 63 mmCL. Hasil penelitian Jamal (2015) di perairan Takalar menunjukkan ukuran udang windu yang tertangkap trammel net berkisar antara 49-51 $\mathrm{mm}$. Sementara ukuran yang tertangkap di perairan Kakkaithevu, Srilanka berkisar 96-189 mm (Piratheepa et al., 2013) Ukuran minimum yang tertangkap di perairan Tarakan ini lebih kecil daripada di perairan Takalar dan di India Selatan. Adanya perbedaan ukuran tersebut kemungkinan dipengaruhi oleh kondisi lingkungan, alat tangkap dan tekanan penangkapan.

Pola pertumbuhan panjang-berat udang windu menunjukkan bersifat isometric. Piratheepa et al., (2013) juga menemukan hal yang sama pada udang windu di perairan Kakkaithevu, Srilanka, sedangkan Gopalakrishnan et al., (2014) memperlihatkan bahwa di perairan India Selatan pola pertumbuhan udang windu bersifat allometrik negative. Adanya variasi nilai b pada hubungan panjang-berat menunjukkan sifat relatif dari pertumbuhan yang artinya dapat berubah menurut waktu. Apabila terjadi perubahan terhadap lingkungan dan ketersediaan makanan diperkirakan nilai ini juga akan berubah. Variasi nilai ini dapat disebabkan oleh berbagai faktor, seperti jumlah udang contoh yang diukur (semakin banyak contoh akan semakin akurat), kondisi perairan dan musim (Gokhan et al., 2007 dalam Karna et al., 2011). Gulland (1983) serta Sparre \& Venema (1992) menambahkan bahwa variasi nilai b dapat disebabkan oleh berbagai faktor seperti suhu, salinitas, makanan (kuantitas, 
kualitas dan ukuran), jenis kelamin, tahap kematangan gonad, dan kelestarian habitat.

Pada penelitian ini nisbah kelamin antara jantan dan betina menunjukkan $1: 1,4$ artinya populasi udang betina lebih banyak dibanding udang jantan. Hasil penelitian ini berbeda dengan penelitian di pantai Digha, Bengal Barat (India) dimana jumlah jantan lebih banyak dibanding betina (Uddin et al., 2015). Fisher (1958) menyatakan bahwa secara umum idealnya nisbah kelamin di alam mendekati 1 : 1. Berdasarkan nisbah kelamin ini menunjukkan tekanan penangkapan masih belum terlalu tinggi. Naamin (1984) menyatakan bahwa apabila di suatu perairan terjadi tekanan penangkapan yang tidak begitu tinggi maka selalu udang betina lebih banyak dari udang jantan.

Pengetahuan mengenai musim pemijahan sangat penting untuk pengelolaan perikanan. Selain melalui sebaran densitas telur, musim pemijahan dapat diketahui melalui pengamatan tingkat kematangan gonad. Berdasarkan hasil pengamatan, udang windu matang gonad terjadi pada bulan Maret-April dan September. Hal ini menunjukkan puncak musim pemijahan udang windu terjadi pada bulan Maret / April dan September. Hasil sama dipresentasikan oleh Motoh (1981) yang menyatakan bahwa udang windu di Filipina memijah sepanjang tahun dengan dua puncak musim pemijahan yaitu Februari-Maret atau Juli dan Oktober-November walaupun bervariasi dari tahun ke tahun. Rajyalakshmi et al., (1985) menambahkan bahwa musim pemijahan udang windu di pantai Odisha terjadi antara Oktober sampai April.

Perhitungan ukuran pertama kali matang gonad $\left(\mathrm{L}_{\mathrm{m}}\right)$ dan rata-rata ukuran tertangkap (Lc) dapat dijadikan dasar dalam penentuan ukuran minimum udang yang boleh ditangkap (minimum legal size). Pada penelitian ini ukuran pertama kali matang gonad udang windur adalah 33,58 mmCL dan ukuran rata-rata tertangkap adalah 40,69 mmCL. Ukuran yang tertangkap umumnya masih lebih besar dari ukuran pertama kali matang gonadnya. Berdasarkan ukuran tersebut dapat kita tentukan bahwa sebaiknya ukuran udang yang tertangkap di atas 33,58 mmCL. Pinheiro \& Lins-Oliveira (2006) menyatakan apabila ukuran yang tertangkap lebih rendah dibandingkan dengan nilai $\mathrm{L}_{\mathrm{m}}$ maka akan mengakibatkan penurunan stok udang akibat terhambatnya proses rekruitmen.

\section{KESIMPULAN}

Penelitian udang windu (Penaeus monodon) di perairan Tarakan diperoleh pola pertumbuhan panjangberat udang windu bersifat isometrik dan melakukan pemijahan sepanjang tahun dengan puncaknya pada bulan Maret-April dan September. Nisbah kelamin udang berada dalam kondisi tidak seimbang dengan didominasi oleh betina. Rata-rata ukuran pertama kali tertangkap (Lc) adalah pada panjang karapas 40,69 mmCL serta rata-rata ukuran matang gonad (Lm) udang betina adalah 33,58 mmCL.

\section{PERSANTUNAN}

Tulisan ini merupakan bagian dari kegiatan "Penelitian karakteristik biologi perikanan, habitat sumber daya ikan/ udang dan potensi produksi sumberdaya perikanan di WPP 716 (Laut Sulawesi dan sebelah Utara Pulau Halmahera) pada Balai Penelitian Perikanan Laut Muara Baru, Jakarta Tahun Anggaran 2016. Penulis juga mengucapkan terima kasih kepada petugas enumerator di Tarakan yang telah membantu dalam pengumpulan data selama penelitian.

\section{DAFTAR PUSTAKA}

Balai Penelitian Perikanan Laut. (2012). Laporan penelitian pengkajian stok dan pengusahaan sumberdaya udang penaeid dan rajungan di wilayah pengelolaan perikanan 712 Laut Jawa dan 716 Laut Sulawesi. Jakarta. p. 132.

Direktorat Jenderal Perikanan Tangkap. (2015). Statistik perikanan tangkap menurut Provinsi Tahun 2014.

Fisher, R.A. (1958). The genetical theory of natural selection (p. 304). Dover, New York, 2nd edition.

Gopalakrishnan, A., Rajkumar, M., Rahman, M.M., Sun, J., Anthony, P.J., Venmathi, Maran, B.A. \& Trilles, J.P. (2014). Length-weight relationship and condition factor ofwild, grow-out and loose-shell affected giant tiger shrimp, Penaeus monodon (Fabricus, 1798) (Decapoda: Penaeidae). J. Appl Ichthyol (30), 251-253.

Gulland, J.A. (1983). Fish stock assessment. A Manual of Basic Methods (p. 233). John Wiley \& Sons. Chicester.

Hedianto, D.A., Suryandari, A. \& Tjahjo, D. W. H. (2016). Dinamika populasi dan status pemanfaatan udang windu Penaeus monodon (Fabricus, 1789) Di Perairan Aceh Timur, Provinsi Aceh. J.Lit. Perikan. Ind. 22 (2), 72 .

Jamal, M. (2015). Selektifitas alat tangkap trammel net terhadap udang penaeid di Kabupaten Takalar Propinsi Sulawesi Selatan Torani, 25 (2), 96-105.

Jennings, S., Kaiser, M. \&. Reynolds, J.D. (2001). Marine fisheries ecology (p. 417). Alden Press Ltd. Blackwell Publishing. United Kingdom.

Karna, S.K., Panda, S. \& Guru, B.C. (2011). Length-weight relationship (Lwr) and seasonal distribution of Valamugil speigleri (Valancienues) through size 
frequency variation and landing assessment in Chilika Lagoon, India. Asian J. Exp. Biol. Sci. 2(4), 654-662.

Kembaren, D. D. \& Nurdin, E. (2013). Dinamika populasi dan tingkat pemanfaatan udang windu (Penaeus monodon) di Perairan Tarakan, Kalimantan Timur. J.Lit. Perikan. Ind. 19 (4), 221-226.

Kembaren, D.D. \& Suman, A. (2013). Biology and population dynamics of Banana shrimp (Penaeus merguiensis) in the Tarakan waters, East Borneo. Ind. Fish Res.J. 19 (2), 99-105.

Lagler, K.F. (1972). Freshwater fishery biology (p. 421). W.M.C. Brown Company Publisher. Dubuque, Iowa.

Motoh, H. (1981). Studies on the fisheries biology of the giant tiger prawn, Penaeus monodon, in The Philippines. SEAFDEC Tech. p 128.

Naamin, N. (1984). Dinamika populasi udang putih (Penarus merguiensis de Mann) di perairan Arafura dan alternative pengelolaannya. Disertasi. Fakultas Pasca Sarjana. Institut Pertanian Bogor, p. 277.

Nurdin, E. \& Kembaren, D.D. (2015). Parameter populasi udang putih (Penaeus merguiensis) di Perairan Sampit dan sekitarnya, Kalimantan Tengah. J.Lit. Perikan. Ind., 7 (2), 103-109.

Pinheiro, A.P. \& Lins-Oliveira, J.E. (2006). Reproductive biology of Panulirus echinatus (Crustacea: Palinuridae) from São Pedro and São Paulo Archipelago, Brazil. Nauplius. 14(2): 89-97.Hill, B.J. 1982. The Queensland Mud Crab Fishery. Queensland Fish Inf. Australia. p. 7.

Piratheepa, U., Edrisinghe \& Chitravadivelu, K. (2013). Relationship of Penaeus monodon (Fabricius, 1798) in Kakkaithevu Coastal Waters in the Northern Part of Sri Lanka S. Tropical Agricultural Research, 25 (1), $133-140$

Rajyalakshmi, T., Pillai, S.M. \& Ravichandran, P. (1985). The biology of Penaeus monodon in the capture fisheries of Orissa coast in the context of occurrence of natural brood stock. In: Y. Taki, J.H. Primavera, J.A. Liborera (Eds.). First International Confurence. Culture of penaeid prawn and shrimp, 1984 December 4-7; Iloilo City, Philippines, SEAFDEC Aquaculture Department, $175 \mathrm{p}$.
Saputra, S.W. \& Subiyanto. (2007). Dinamika populasi udang putih (Penaeus merguiensis de Mann 1907) di Laguna Segara Anakan, Cilacap, Jawa Tengah. Ilmu Kelautan. Universitas Diponegoro, 12 (3), 157-166.

Saputra, S.W., Djuwito \& Rutiyaningsih, A. (2013). Beberapa aspek biologi udang jerbung (Penaeus merguiensis) di perairan pantai Cilacap Jawa Tengah. Journal of Management of Aquatic Resources, 2 (3), 47-55.

Steel, R.G.H. \& Torrie, J.S.H. (1989). Prinsip dan prosedur statistika: suatu pendekatan biometric (p. 748). Terjemahan. Edisi kedua. PT Gramedia Pustaka Utama. Jakarta.

Sparre, P. \& Venema, S.C. (1992). Introduksi pengkajian stok ikan tropis (p. 438). Buku 1: Manual. Organisasi Pangan dan Petanian Perserikatan Bangsa-Bangsa dan Pusat Penelitian dan Pengembangan Perikanan, Badan Penelitian dan Pengembangan Pertanian. Jakarta.

Suman, A. (1992). Population dynamics of endeavour shrimp (Metapenaeus ensis de Mann) in the Southern inshore of Java. Proceeding of the First Seminar on Marine and Coastal Ecology: 64-71 (in Indonesian).

Suman, A. \& Boer, M. (2005). Size at first maturity, spawning season and growth parameters of endeavour shrimp (Metapenaeus ensis de Mann) in Cilacap and adjacent waters. Ind. Fish Res.J. 11 (2), 65-71.

Suman, A. \& Umar, C. (2010). Dinamika populasi udang putih (Penaeus merguiensis de Mann) di perairan Kotabaru, Kalimantan Selatan. J. Lit.Perikan Ind., 16 (1), 29-33.

Uddin, N., Ghosh, Shubhadeep, Maity \& Joydev. (2015). Reproductive biology, maturation size and sex ratio of black tiger shrimp (Penaeus monodon Fabricius, 1798) from fishing grounds of Digha coast, West Bengal, India. International Journal of Aquatic Biology Karaj, 3(6), 372-378.

Udupa, K.S. (1986). Statistical method of estimating the size of first maturing in fishes. Fishbyte. 4(2), 8-10. 